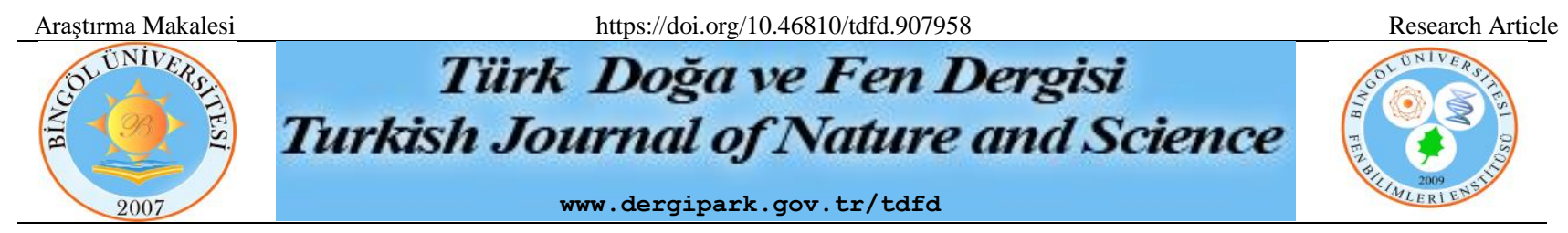

\title{
Bingöl Üniversitesi Öğrencilerinin Attk Yönetimi - Geri Dönüşüm ve Çevre Konusundaki Bilinç ve Uygulama Düzeyleri Üzerine Bir Araştırma
}

\author{
Ayşenur AKBANA ${ }^{1 *}$, Müge YURTCAN ${ }^{2}$ \\ ${ }^{1}$ Bingöl Üniversitesi, Ziraat Fakültesi, Peyzaj Mimarlığı Bölümü, Bingöl, Türkiye \\ ${ }^{2}$ Bingöl Üniversitesi, Teknik Bilimler MYO, Park ve Bahçe Bitkileri Bölümü, Bingöl, Türkiye \\ Ayşenur AKBANA ORCID No: 0000-0003-0394-7278 \\ Müge YURTCAN ORCID No: 0000-0003-1210-2787
}

*Sorumlu yazar: abektas@bingol.edu.tr

(Alınış: 01.04.2021, Kabul: 14.06.2021, Online Yayınlanma: 31.12.2021)

\begin{abstract}
Anahtar
Kelimeler

Atık yönetimi,

Bingöl

Üniversitesi.

Çevre bilinci,

Geri dönüşüm
\end{abstract}

\begin{abstract}
Öz: Dünya üzerinde nüfus ve teknolojik gelişmelere bağlı olarak yaşam standartları her geçen gün artarken, tüketim de büyük oranda artış göstermektedir. Çevre sorunlarının ortaya çıkmasındaki temel etkenlerden biri tüketim hızındaki artış ve buna bağlı olarak üretilen atık miktarının çevre tarafından sindirilebilecek düzeyin çok üstüne çıkmış olmasıdır. Sürdürülebilir bir çevrenin sağlanmasında özellikle 21. yy'la birlikte dünya çapında atık yönetimi ve geri dönüșüm konuları önem kazanmıştır. Bu konuda oluşturulan ulusal ve uluslararası politikalar yanında bireysel tutum ve davranışlarda son derece önem taşımaktadır. Bu çalışma kapsamında Bingöl Üniversitesi öğrencilerinin atık yönetimi - geri dönüşüm ve çevre konusundaki bilinç ve uygulama düzeylerini saptanmaya yönelik olarak anket çalışması gerçekleştirilmiştir. Anket sonuçlarından elde edilen veriler SPSS 22. programında analiz edilmiştir. Ağırlıklı olarak atık geri dönüşüm hiyerarşisinin ilk dört basamağını oluşturan ve daha çok bireysel anlamda katkı sağlamanın olanaklı olduğu; önleme, azaltma, tekrar kullanım ve geri dönüştürme konularını kapsayan anket sonucunda ortaya çıkan veriler yorumlanarak bir değerlendirme gerçekleştirilmiş ve atılması gereken adımlar konusunda önerilere yer verilmiştir.
\end{abstract}

\section{A Research on the Awareness and Practice Levels of Bingöl University Students on Waste Management - Recycling and Environment}

Keywords

Waste

management,

Bingöl

University,

Environmental

awareness,

Recycling.

\begin{abstract}
While living standards are increasing day by day due to population and technological developments in the world, consumption also increases significantly. Because one of the main factors in the emergence of environmental problems is the increase in the rate of consumption, the amount of the produced waste exceed the level that can be digested by the environment. Waste management and recycling issues to provide a sustainable environment have gained importance around the world especially in the 21 st century. In addition to national and international policies created in this regard, individual attitudes and behaviors are extremely important. Within the scope of this study, a survey was conducted to determine the awareness and application levels of Bingöl University students about waste management - recycling and environment. Survey outcomes were analysed by SPSS 22. programme. Survey outcomes were analysed by SPSS 22. programme. After survey outcomes that predominantly constitutes the first four steps of the waste recycling hierarchy as prevention, reduction, reuse and recycling being got possible by individual contributions was commented, steps to be taken are indicated.
\end{abstract}

\section{GIRIŞ}

Genel bir tanımlamayla çevre; insan faaliyetleri ve tüm canlılar üzerinde kısa ya da uzun vadede, dolaylı yada dolaysız şekilde etkide bulunabilecek biyolojik, fiziksel, kimyasal ve toplumsal etkenlerin belirli bir zaman içerisindeki toplamıdır [1]. 2872 sayılı Çevre Kanununda ise çevre; "Canlıların yaşamları boyunca ilişkilerini sürdürdükleri ve karşılıklı olarak etkileşim içinde bulundukları biyolojik, fiziksel, sosyal, ekonomik ve kültürel ortam" olarak ifade edilmektedir [2]. Başta ekonomik faaliyetler olmak üzere insanların sosyal, kültürel, sanatsal tüm faaliyetleri sonucunda çevre 
üzerinde oluşan olumsuz etkiler [3], doğanın kendisini yenileyebilmesi sayesinde ilk zamanlarda fark edilmemiş, sonraları ise çevrenin oluşan bu zararlanmaları yok edeceği inanışı yaygınlaşmışıtır $[1,4]$.

Özellikle Sanayi Devrimi sonrası yaşanan teknolojik ve ekonomik gelişmeler, çevresel değerlerin bozunuma uğraması ve yok edilmesine, toplumların pek çok alanda gösterdiği gelişime karşıt olarak, açlık, kıtlık, sera etkisi vb. küresel ölçekteki sorunlara etkili çözümler geliştirememeleri ve insanın geleceğinin de tehdit altında olması, 20. yy'ın ilk yarısından itibaren dikkatleri büyük ölçüde çevre üzerine çekmiştir [1]. Sanayi Devrimi'yle birlikte giderek yaygınlaşan sanayi kuruluşlarının olumsuz etkileriyle oluşan atık ve artıkların bir çevre sorunu olarak görülmeye başlanması da yine aynı dönemlerde olmuştur [4]. Çevre üzerinde meydana gelen değişimlerin negatif yönde özellikler göstermesi çevre sorunları olarak değerlendirilmekte [5] ve bu sorunlar insanların doğal kaynakları bilinçsizce ve aşırı derecede tüketmesi, böylelikle doğal dengeyi bozması ve çevreye verdiği zarar neticesinde ortaya çıkmaktadır [6]. Gıda güvenliği ve su kaynakları üzerinde tehdit oluşturan, insan ve doğadaki tüm canlıların sağlığı ile çevrenin sürdürülebilirliğini tehlikeye sokan çevre sorunları, kısa vadede yerel sorunlar olarak algılansa da, özellikle uzun vadede ülke sınırlarını aşan küresel etkilere sahiptir. Küresel ısınma ve buna bağlı iklim değişiklikleri, biyolojik çeşitliliğin azalması, çölleşme, ozon tabakasındaki tahribat, hava, su ve toprak kirlilikleri, asit yağmurları öne çıkan küresel çevre sorunları arasında sayllabilir [7]. Çevre üzerinde oluşan tüm olumsuzluklar neticesinde, temel amacı doğal kaynaklar üzerindeki insan kaynaklı baskıyı azaltmak, çevre kalitesini koruyarak, toplumsal refahı ve yaşam kalitesini üst seviyelere çıkarmak olan çevre politikalarının [8] oluşturulması özellikle 1970'li yıllardan itibaren uluslararası boyutta önem kazanmıştır.

Uluslararası çevre politikalarını belirlemeye yönelik olarak atılan ilk adım BM'nin öncülüğünde 1972 yılında düzenlenen, "tek bir dünyamız var" sloganının belleklere yerleştirildiği ve çevre sorunlarının evrenselliğinin ilk kez kabul edildiği Stockholm BM İnsan Çevresi Konferansı olmuştur [1]. Bu gelişmeyi sırasıyla 1987'de Dünya Çevre Kalkınma Komisyonu tarafından hazırlanan "Ortak Geleceğimiz" ya da bilinen diğer bir adıyla Brundtland Raporu, 1992 yllında düzenlenen Rio Çevre ve Kalkınma Konferansı, 2000 yılında gerçekleştirilen BM Binyıl Zirvesi, 2002 yılında düzenlenen Johannesburg Sürdürülebilir Kalkınma Zirvesi (Rio+10), 2012 BM Sürdürülebilir Kalkınma Konferans1 (Rio+20) ve 2015 BM Sürdürülebilir Kalkınma Zirvesi izlemiştir. Uluslararası boyutta atılan tüm bu adımlar çevre ve sürdürülebilir kalkınma konularında önemli dönüm noktaları olmuştur [8].

Çevre sorununun ortaya çıkmasındaki temel etkenlerden biri insanlar tarafından üretilen atık miktarının çevre tarafından sindirilebilecek düzeyin çok üstüne çıkmış olmasıdır [9]. Dünya çapında her yıl 2,1 milyar ton yani yaklaşık olarak 800.000 olimpik yüzme havuzunu dolduracak kadar çöp ortaya çıkmakta ve bunların sadece yüzde 16'sının geri dönüşümü sağlanmaktadır. Çöplerin yüzde 46'sı ise geri dönüşümü sağlanamayacak şekilde atılmaktadır [10]. Kontrolsüz bir şekilde doğaya bırakılan atıkların, doğada yok olma süreleri bazen yüzlerce hatta binlerce yılı bulabilmektedir. Örneğin; bir cam şişe doğada 4000 yılda yok olurken, bir plastik malzeme 1000 yılda, bir teneke kutu 10-100 yıl aralığında yok olmaktadır [11]. Plastik, cam, metal vb. atıkların doğaya karışması toprak, su ve hava kirliliğine yol açmakta, geri dönüşümün sağlanamaması durumunda yeniden üretim sürecinde gerek ham madde ihtiyacı gerekse harcanan enerji doğal kaynaklara verilen zararı arttırmaktadır. İstatistiksel veriler 1şı̆̆ında bakıldığında; 1 ton cam atığın geri dönüşümü sayesinde, 100 litre petrol tasarrufu sağlanabileceği, 1 ton kâğıtkarton atı̆̆ın geri dönüşümü sayesinde 17 ağacin kesilmesinin önlenebileceği, dünya çapında kâğıt atıkların yarısının geri dönüşümünün sağlanması durumunda ise her yıl 8 milyon hektar ormanın korunabileceği belirtilmektedir [12].

Dünyada geri dönüşüm konusunda en başarılı ülkeler arasında Avusturya, İngiltere, İtalya, Fransa Almanya, Tayvan, Misır, Brezilya, Singapur ve Güney Kore, ilk sıralarda yer almaktadır. Geri dönüşüm oranının en yüksek olduğu Avusturya, atıklarının yüzde 63'ünü geri kazanabiliyorken, Almanya ve Tayvan'da bu oran \%60 dolaylarındadır [13]. Türkiye'de ise 2014 yılında 27 milyon ton belediye atığı oluştuğu, oluşan atıkların, $\% 64$ 'ünün düzenli depolama, \% 30'unun vahşi depolama (kontrolsüz, çöplük) yöntemiyle bertaraf edildiği, sadece \% 6'sının geri dönüşümünün sağlandığı kaydedilmiştir [14].

Nüfus artışı, sanayileşme ve ekonomik büyümeye bağlı olarak tüketim hızı giderek artmakta, buna bağlı olarak ortaya çıkan atık miktarı da gün geçtikçe artış göstermektedir. Tüketim de yaşanan bu artış, nüfus artışının da çok üzerinde seyretmektedir. Örneğin; Sawin [15]'e göre 1850-1970 yılları arasında dünya nüfusu yaklaşık üç kat artış gösterirken, enerji kullanımı yaklaşık 12 kat artmıştır. Atık miktarında her geçen gün meydana gelen artış çevresel, sosyal ve ekonomik alanda pek çok olumsuzluğu da beraberinde getirmekte [16], kaynakların hızla tükenmesi ve sinırsız olmaması kaynakların daha etkin kullanılmalarını zorunlu kılmaktadır. $\mathrm{Bu}$ durum atık miktarının azaltılması, meydana gelen atığın tekrar kullanımı ve ham maddeye dönüştürülmesi gibi süreçleri kapsayan atık yönetimini zorunlu hale getirmektedir.

Üretim faaliyetleri ve kullanım sonucunda ortaya çıkan, doğrudan ya da dolaylı olarak alıcı ortama verilmesi halinde çevre ve insan sağlı̆̆ını olumsuz yönde etkileyecek her türlü madde atık olarak tanımlanmaktadır [17]. 2 Nisan 2015 tarih ve 29314 sayll Resmi Gazete'de yayınlanan "Attk Yönetimi Yönetmeliği'ne" göre ise atık: "Üreticisi veya fiilen elinde bulunduran gerçek veya tüzel kişi tarafindan çevreye atılan veya bırakılan ya da atılması zorunlu olan herhangi bir madde veya materyal" olarak tanımlanmaktadır [18]. Atık yönetimi ise yine aynı yönetmeliğe göre: "Atığın oluşumunun önlenmesi, kaynağında azaltılması, yeniden 
kullanılması, özelliğine ve türüne göre ayrılması, biriktirilmesi, toplanması, geçici depolanması, taşınması, ara depolanması, geri dönüşümü, enerji geri kazanımı dâhil geri kazanılması, bertarafı, bertaraf işlemleri sonrası izlenmesi, kontrolü ve denetimi faaliyetlerini" ifade etmekte [18] ve Şekil.1.'de gösterildiği gibi altı hiyerarşik basamaktan oluşmaktadır.

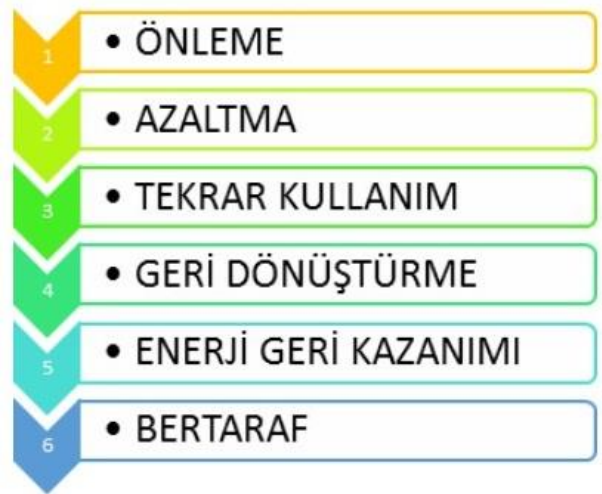

Şekil 1. Atık yönetimi hiyerarşisi

Gerek uluslararası normlar gerekse ulusal öncelikler gözetilerek, sürdürülebilirlik ilkesi doğrultusunda, politika, strateji ve mevzuat geliştirilmesi sorumluluğuyla ülkemizde, T.C. Çevre ve Şehircilik Bakanlığı'nca 2016-2023 yılları arasını kapsayan Ulusal Atık Yönetimi ve Eylem Planı hazırlanmıştır. Bu plana göre; 2023 yılında oluşacak toplam atığın \%35'inin geri dönüşümünün sağlanması, \%65'inin ise düzenli depolama şeklinde bertaraf edilmesi hedefler arasındadır [19]. 2017 yılı itibari ile T.C. Çevre ve Şehircilik Bakanlığı öncülüğünde başlatılan "Sıfır Atık" projesi de bu kapsamda önem taşımaktadır. "Sıfır Atık"; israfın önlenmesi, kaynakların verimli ve etkin kullanımı, atık oluşum sebepleri üzerinde durularak atık oluşumunun olabildiğince engellenmesi veya minimum seviyeye indirilmesi, oluşan atığın ise kaynağında ayrıştırılması ve geri dönüşümünün sağlanmasını kapsayan ve atık yönetim felsefesi olarak ifade edilen bir hedeftir [20].

Atık yönetim felsefesinin yaygınlaştırılması ve çevrenin korunmasında önemli boyutlardan birini kamuoyu bilinci ve etkin katılımı oluşturmaktadır [21]. Bunun yanında toplumsal çevre bilincinin gelişmesinde eğitimin de oldukça büyük rolü bulunmaktadır. Daha duyarlı ve bilinçli bir toplumun oluşması için ise çevre eğitiminin küçük yaşlardan itibaren verilmesi gerekmektedir [22]. Çevre bilincinin oluşturulmasında çevre eğitiminin ögrenim süreçlerine dahil edilmesi yanında kitle iletişim araçlarının da büyük etkisi bulunmaktadır [21]. Çevre koruma ve atık yönetimi konusunda oluşturulan bilincin davranışa dönüştürülmesinde özellikle yerel yönetimler ve kamu kuruluşlarına büyük sorumluluklar düşmektedir. Geri dönüşüme katk1, atık toplama ve geri dönüşüm hizmetleriyle doğrudan bağlantılı olup [23], bu doğrultuda atıkların kaynağında ayrıştırılması için yeterli ekipmanların gerek yerel yönetimler gerekse kamu kurumlarınca temin edilmesi gerekmektedir.

$\mathrm{Bu}$ araştırma kapsamında Bingöl Üniversitesi öğrencilerinin atık yönetimi - geri dönüşüm ve çevre konusundaki bilinç ve uygulama düzeylerini saptanmaya yönelik olarak anket çalışması gerçekleştirilmiştir. Ağırlıklı olarak atık geri dönüşüm hiyerarşisinin ilk dört basamağını oluşturan ve daha çok bireysel anlamda katkı sağlamanın olanaklı olduğu; önleme, azaltma, tekrar kullanım ve geri dönüştürme konularını kapsayan anket sonucunda ortaya çıkan veriler yorumlanarak bir değerlendirme gerçekleştirilmiş ve atılması gereken adımlar konusunda önerilere yer verilmiştir.

\section{MATERYAL VE METOT}

Bu çalışma, 12.03.2020 tarihli, E.5824 sayılı etik kurul onayı ile Bingöl Üniversitesi öğrencileri ile yürütülmüştür. Bingöl Üniversitesi, 15.713 kișilik öğrenci sayısıyla [24], araştırmanın evrenini oluşturmaktadır. Örneklem büyüklüğü, $\mathrm{n}=\frac{N \cdot t^{2} \cdot P \cdot Q}{(N-1) \cdot d^{2}+t^{2} \cdot P \cdot Q}$ formülü ile yaklaşık 0,08 örneklem hata payı ve 0,95 güven aralığında 158 olarak hesaplanmıştır. [25]. Covid19 pandemi sürecinde yürütülen çalışma için katılımcılar rastgele seçilmiştir.

Araștırma bulgularının tüm analizleri SPSS. 22 programı kullanılarak yapılmıştır. Araştırma yapılırken frekans analizleri ve farklılık analizleri uygulanmıştır. Araştırmadaki ifadelerin ortalamasının çarpıklık ve basıklık değeri +2 ve -2 arasında değiştiği için, verilerin normal dağıldığ 1 kabul edilmektedir [26]. Frekans analizlerinde ankete verilen cevapların \%'lik değerleri hesaplanmıştır. Verilerin normal dağılım göstermesinden dolayı, anlamlı farklılık analizleri için, bağımsız 2 değișkenin gösterdiği farklılık $\mathrm{T}$ testi ile; bağımsız değişkenlerin 2'nin üstünde olduğu durumlar için Anova testi ile analiz yapılmıştır. Değişkenler arasındaki farklılığın sebeplerinin analiz edilmesi için post hoc testlerden faydalanılmıştır. Homojen dağılımlı verilerde Tukey, homojen dağılımlı olmayan verilerde Games Howel testleri kullanılmıștır.

\section{BULGULAR}

\subsection{Demografik Bilgiler}

$\mathrm{Bu}$ çalışma kapsamında Bingöl Üniversitesi öğrencilerinin içinden rastgele seçilen toplam 158 katılımcı ile anket yürütülmüştür. Katılımcıların demografik özellikleri Tablo 1'deki gibidir.

Tablo 1. Katılımcıların yaș ve cinsiyet dağılımı

\begin{tabular}{|c|c|c|c|c|c|}
\hline \multicolumn{2}{|c|}{} & \multicolumn{4}{|c|}{ CINSIYET } \\
\cline { 3 - 6 } \multicolumn{2}{c|}{} & \multicolumn{2}{|c|}{ Kadın } & \multicolumn{2}{c|}{ Erkek } \\
\hline \multirow{4}{*}{ YAŞ } & $18-21$ & $25,30 \%$ & 40 & $26,60 \%$ & 42 \\
\cline { 2 - 6 } & $22-25$ & $16,50 \%$ & 26 & $19 \%$ & 30 \\
\cline { 2 - 6 } & $26-30$ & $2,50 \%$ & 4 & $4,40 \%$ & 7 \\
\cline { 2 - 6 } & 31 ve üstü & $0 \%$ & 0 & $5,70 \%$ & 9 \\
\cline { 2 - 6 } & Toplam & $44,30 \%$ & 70 & $55,70 \%$ & 88 \\
\hline
\end{tabular}

Araştırma katılımcılarının \%49,4'ü 1. sınıf; \%28,5'i 2. sınıf; \%6,3'ü 3. sınıf; 10,8'i 4. sınıf; \%5'i lisansüstü öğrencisidir (Tablo 2). Katılımcılar, eğitim ve öğretim gördükleri birimlere bağlı farklı bölüm ve/veya programlardan rastgele seçilmiştir. 
Tablo 2. Katılımcıların okudukları birim ve sınıf dağılımı

\begin{tabular}{|c|c|c|c|c|c|c|c|}
\hline \multirow{2}{*}{ BİRİM } & \multicolumn{7}{|c|}{ SINIF } \\
\hline & $\mathbf{1}$ & 2 & 3 & 4 ve üstü & Lisansüstü & Toplam & $\%$ \\
\hline Sosyal Bil. MYO & 2 & 7 & 0 & 0 & 0 & 9 & 5,7 \\
\hline Gıda Tarım Hayvancılık MYO & 5 & 2 & 0 & 0 & 0 & 7 & 4,4 \\
\hline Mim. Müh. Fak. & 11 & 1 & 1 & 7 & 0 & 20 & 12,7 \\
\hline Teknik Bil. MYO & 21 & 14 & 0 & 0 & 0 & 35 & 22,2 \\
\hline Fen Edebiyat Fak. & 0 & 0 & 6 & 0 & 0 & 6 & 3,8 \\
\hline Yabanc1 Diller YO & 0 & 6 & 3 & 9 & 0 & 18 & 11,4 \\
\hline Sağlık Hizmetleri MYO & 30 & 6 & 0 & 0 & 0 & 36 & 22,8 \\
\hline BESYO & 7 & 1 & 0 & 0 & 0 & 8 & 5 \\
\hline Ziraat Fak. & 0 & 2 & 0 & 0 & 4 & 6 & 3,8 \\
\hline Veterinerlik Fak. & 2 & 5 & 0 & 1 & 0 & 8 & 5 \\
\hline İktisadi İdari Bilimler Fak. & 0 & 1 & 0 & 0 & 4 & 5 & 3,2 \\
\hline
\end{tabular}

Katılımcıların tamamı öğrenciler arasından seçildiği için gelir durumları öğrenim kredisi/bursu göz önünde bulundurularak sorulmuştur. Katılımcıların \%57,6's1 1000 TL alt1; \%16,4'i 1000-2000 TL aras1; \%13,3'ü 2001-3000 TL arasi; \%12,7'si 3000 TL üstü aylık gelire sahiptir.

\subsection{Atık Yönetimi ve Çevre Bilinci Ölçeği Derecelendirme Değerlendirmesi}

Geri dönüşüm ve çevre bilinç düzeyinin ölçüldüğü ankette 2 farklı ifade tipi kullanılmıştır. Birinci ifade tipinde, ana başlık altında yöneltilen farklı ifadelerin puanlanması istenmiştir. İkinci ifade tipinde ise katılımcılardan, sorulan kapalı uçlu sorulara cevap vermeleri istenmiştir.
Katılımcılardan, organik atıklar (sebze, meyve, yiyecek artıkları vb.), kağıt atıklar, plastik atıklar, cam atıklar, kimyasal atıklar (deterjan, zirai ilaç, pil vb.), petrol ürünleri atıkları (kauçuk, yakıt vb.), metal atıklar, tıbbi atıklar ve tekstil atıkları olarak gruplandırılmış 9 farklı atık türünün, zarar derecesinin çevre üzerine etkilerinin puanlandırılması istenmiştir. Verilen cevapların ortalaması alındığı zaman, en yüksek puanı kimyasal atıkların aldığı görülmüsstür. Kimyasal atıkları takiben plastik atıklar, petrol ürünlerinin atıkları, tıbbi atıklar, cam atıklar ve tekstil atıkları zararlı atıklar olarak derecelendirilmiştir. Katılımcılar organik atıkları ve kağıt atıkları nispeten daha zararsız olarak değerlendirmişlerdir (Tablo 3).

Tablo 3. Atıkların Çevre Üzerine Zararının Derecelendirilmesi

\begin{tabular}{|c|c|c|c|c|c|c|c|c|c|}
\hline \multirow{2}{*}{\begin{tabular}{|l|} 
Puan \\
\end{tabular}} & \multicolumn{9}{|c|}{ Atık Sınıflarının Çevre Üzerine Zarar Derecelendirmesi } \\
\hline & Organik & Kağıt & Plastik & Cam & Kimyasal & Petrol & Metal & Tibbi & Teksti \\
\hline 1 & 94 & 16 & 0 & 3 & 1 & 0 & 5 & 3 & 2 \\
\hline 2 & 34 & 65 & 4 & 12 & 3 & 6 & 8 & 7 & 12 \\
\hline 3 & 19 & 46 & 13 & 25 & 6 & 11 & 24 & 15 & 30 \\
\hline 4 & 6 & 19 & 27 & 45 & 27 & 31 & 36 & 36 & 54 \\
\hline $\mathbf{5}$ & 5 & 12 & 114 & 73 & 121 & 110 & 85 & 97 & 60 \\
\hline Toplam & 158 & 158 & 158 & 158 & 158 & 158 & 158 & 158 & 158 \\
\hline Ortalama & 1,696 & 2,658 & 4,589 & 4,095 & 4,671 & 4,551 & 4,190 & 4,373 & 4 \\
\hline \multicolumn{9}{|c|}{ Genel Ortalama } & 3,869 \\
\hline
\end{tabular}

Katılımcılardan, su kaynakları (denizler, göller, akarsular vs.), hava, toprak ve besin maddesi olarak adlandırılan 4 farklı kaynak üzerine atıkların baskısının değerlendirilmesi istenmiştir. Verilen puanların ortalaması alındığında katılımcıların, atık maddelerin en çok su kaynakları üzerinde olumsuz etkiye sahip olduğu yönünde puanlama yaptığı görülmektedir. Su kaynaklarını Toprak, besin maddesi ve hava takip etmektedir (Tablo 4).

Tablo 4. Atıkların kaynaklar üzerine baskı derecesi

\begin{tabular}{|c|c|c|c|c|}
\hline & \multicolumn{4}{|c|}{ Atıkların Kaynaklar Üzerindeki Baskı Derecesi } \\
\hline Puan & Su & Hava & Toprak & Besin Maddesi \\
\hline $\mathbf{1}$ & 14 & 16 & 10 & 8 \\
\hline $\mathbf{2}$ & 4 & 3 & 14 & 10 \\
\hline $\mathbf{3}$ & 16 & 20 & 18 & 28 \\
\hline $\mathbf{4}$ & 26 & 48 & 34 & 35 \\
\hline $\mathbf{5}$ & 98 & 71 & 92 & 77 \\
\hline Toplam & 158 & 158 & 168 & 158 \\
\hline Ortalama & 4,203 & 3,981 & 4,095 & 4,032 \\
\hline Genel Ortalama & & & 4,078 \\
\hline
\end{tabular}

Katılımcılara sürdürülebilir bir çevre için bazı unsurların önem derecelerinin puanlandırılması istenmiştir. Verilen cevapların ortalamasına bakıldığı zaman katılımcıların en çok su tasarrufuna önem verdiği görülmektedir. Enerji tasarrufu, yiyecek israfının önlenmesi, geri dönüşüm, çöplerin uygun biçimde bertaraf edilmesi, fosil yakıt kullanımının azaltılması, tekstil ürünlerinin israfının önlenmesi birbirini takip eden unsurlar olarak görülmektedir (Tablo 5).

Tablo 5. Sürdürülebilir çevre için unsurların önem derecesi

\begin{tabular}{|c|c|c|c|c|c|c|c|}
\hline & Sürdi & ülebili & Çevre & cin Uns & Irların & nem D & recesi \\
\hline Puan & ET & ST & GD & YİÖ & TİÖ & FKA & ÇUB \\
\hline 1 & 4 & 3 & 5 & 3 & 4 & 10 & 8 \\
\hline 2 & 3 & 4 & 1 & 4 & 11 & 3 & 2 \\
\hline 3 & 17 & 11 & 22 & 18 & 29 & 22 & 18 \\
\hline 4 & 28 & 19 & 26 & 32 & 40 & 31 & 24 \\
\hline 5 & 106 & 121 & 104 & 101 & 74 & 92 & 106 \\
\hline Toplam & 158 & 158 & 158 & 158 & 158 & 158 & 158 \\
\hline Ortalama & 4,449 & 4,589 & 4,411 & 4,418 & 4,070 & 4,215 & 4,380 \\
\hline Genel Ort & lama & & & & & & 4,362 \\
\hline
\end{tabular}

Katılımcılardan plastik, kağıt, cam, metal, pil, tekstil ve organik atıklardan her birinin geri dönüşümüne bulundukları katkıyı puanlandırmaları istenmiştir. 
Verilen puanların ortalamalarına bakıldığında en fazla plastik atıkların geri dönüşümüne katkı sağladıkları görülmektedir. Plastik atıkları kâğıt atıklar ve cam atıklar takip etmektedir. Tekstil atıkları ve metal atıkların en düşük puana sahip olduğu görülmektedir (Tablo 6).

Tablo 6. Geri dönüşüme katılımcıların kişisel katkı derecelendirmesi

\begin{tabular}{|c|c|c|c|c|c|c|c|}
\hline & \multicolumn{7}{|c|}{ Geri Dönüşüme Kişisel Katkı Derecelendirmesi } \\
\hline Puan & Kağıt & Plastik & Cam & Metal & Pil & Tekstil & Organik Atık \\
\hline 1 & 11 & 4 & 15 & 34 & 29 & 39 & 36 \\
\hline 2 & 8 & 19 & 18 & 36 & 21 & 37 & 26 \\
\hline 3 & 29 & 26 & 39 & 33 & 32 & 36 & 33 \\
\hline 4 & 35 & 31 & 35 & 17 & 19 & 21 & 21 \\
\hline 5 & 75 & 78 & 51 & 38 & 57 & 25 & 42 \\
\hline Toplam & 158 & 158 & 158 & 158 & 158 & 158 & 158 \\
\hline Ortalama & 3,981 & 4,013 & 3,563 & 2,930 & 3,342 & 2,722 & 3,044 \\
\hline \multicolumn{7}{|l|}{ Genel Ortalama } & 3,371 \\
\hline
\end{tabular}

Katılımcılardan sürdürülebilir bir çevre için alınabilecek kişisel önlemlerin puanlandırılması istenmiştir Denklerin günlük yaşantılarında belirtilen kişisel önlemleri uygulama derecelerinin saptanması için ortalamalara bakıldığ 1 zaman, en çok alınan önlemin açık unutulan muslukların kapatılması (AMK) gelmektedir. Bunu takiben açık unutulan lambaların kapatılması (ALK), kısa mesafeler (10-15 dk yürüme mesafesi) için yürümenin tercih edilmesi (KMYT) ve kullanılmadığg zaman elektronik aletlerin (tv, bilgisayar, küçük ev aletleri vb.) fişinin çekilmesi gelmektedir. Katılımcıların aldığı kişisel önlemlerde en düşük puanı 2. el kıyafet kullanımı (2.EKK) almıştır ve onu kişisel su matarası kullanımı (KSMK) takip etmiştir (Tablo 7)

Tablo 7. Sürdürülebilir çevre için alınan kişisel önlemler

\begin{tabular}{|c|c|c|c|c|c|c|c|c|c|c|c|c|}
\hline & \multicolumn{10}{|c|}{ Sürdürülebilir çevre için kişisel önlemlerin derecelendirilmesi } \\
\hline Puan & KSMK & $\mathbf{2 . E K K}$ & STD & ALK & AFC & KMYT & SHP & AÖKK & E-KF & AMK & KTK & SMK \\
\hline $\mathbf{1}$ & 25 & 56 & 5 & 2 & 3 & 5 & 5 & 11 & 21 & 2 & 2 & 4 \\
\hline $\mathbf{2}$ & 15 & 26 & 8 & 6 & 6 & 4 & 10 & 10 & 24 & 4 & 11 & 8 \\
\hline $\mathbf{3}$ & 37 & 35 & 24 & 9 & 20 & 24 & 26 & 32 & 27 & 10 & 28 & 27 \\
\hline $\mathbf{4}$ & 26 & 20 & 38 & 32 & 30 & 19 & 32 & 25 & 23 & 17 & 28 & 34 \\
\hline $\mathbf{5}$ & 55 & 21 & 83 & 109 & 99 & 106 & 85 & 80 & 63 & 125 & 89 & 85 \\
\hline Toplam & 158 & 158 & 158 & 158 & 158 & 158 & 158 & 158 & 158 & 158 & 158 & 158 \\
\hline Ortalama & 3,449 & 2,519 & 4,177 & 4,519 & 4,367 & 4,373 & 4,152 & 3,968 & 3,525 & 4,639 & 4,209 & 4,190 \\
\hline
\end{tabular}

KSMK: Kişisel su matarası kullanımı, 2.EKK: 2. El kıyafet kullanımı, STD: Banyo, wc kullanırken su tüketimine dikkat edilmesi, ALK: Açık unutulmuş lambaların kapatılması, AFÇ: Kullanılmadığ zaman elektronik aletlerin (tv, bilgisayar, küçük ev aletleri vb.) fişinin çekilmesi, KMYT: Kısa mesafeler (10-15 dk yürüme mesafesi) için yürümenin tercih edilmesi, SHP: Yiyecek fazlasinın sokak hayvanları ile paylaşılmasl, AÖKK: Arkalı önlü kağıt ve 2. el kitap kullanımı, E-KF: E-kitap, E-fatura, E-ders notlarının kullanımı, AMK: Açık unutulan muslukların kapatılması, KTK: Boş kavanoz ve kapların tekrar tekrar kullanılması, SMK: Sebze ve meyvelerin mevsiminde veya konserve olarak tüketilmesi.

Katılımcılar geri dönüşüm ile ilgili bilinç oluşturma etkisi konusunda en yüksek puanı internet seçeneğine vermişleridir. Sonrasında televizyon gelmektedir.
Katılımcıların bilinçlenmede etkisini en düşük puanlandırdıkları medya organı radyodur ve sonrasında gazete ve dergiler gelmektedir (Tablo 8).

Tablo 8. Geri dönüşüm bilinci konusunda medya organlarının etki derecelendirmesi

\begin{tabular}{|c|c|c|c|c|c|c|}
\hline 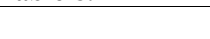 & \multicolumn{6}{|c|}{ Geri Dönüşüm Bilinci İçin Medya Etkisi } \\
\hline Puan & İnternet & $\mathbf{T v}$ & Radyo & Gazete/Dergi & Kitap & Afiș/Broșür \\
\hline 1 & 9 & 7 & 47 & 31 & 20 & 10 \\
\hline 2 & 7 & 10 & 47 & 36 & 26 & 15 \\
\hline 3 & 19 & 31 & 42 & 48 & 49 & 51 \\
\hline 4 & 29 & 37 & 13 & 26 & 34 & 34 \\
\hline 5 & 94 & 73 & 9 & 17 & 29 & 48 \\
\hline Toplam & 158 & 158 & 158 & 158 & 158 & 158 \\
\hline Ortalama & 4,215 & 4,006 & 2,304 & 2,759 & 3,165 & 3,601 \\
\hline \multicolumn{6}{|l|}{ Genel Ortalama } & 3,342 \\
\hline
\end{tabular}

Katılımcılar atık miktarının artış nedenlerine ilişkin yaptıkları değerlendirmede en yüksek puanı israfın artması seçeneği almıştır. Çevre bilincinin yeterli düzeyde olmaması, nüfus artış1, tüketim alışkanlıklarındaki değişim ve tüketim malzemelerine erişim kolaylığı birbirini takip eden faktörler olarak puanlandırılmıştır. Ekonomik alım gücünün artışı atık miktarının artış sebeplerinin derecelendirilmesinde en düşük puan ortalamasına sahip unsurdur (Tablo 9).
Tablo 9. Atık miktarının artış nedenlerinin derecelendirilmesi

\begin{tabular}{|c|c|c|c|c|c|c|}
\hline & \multicolumn{1}{|c|}{ Atk Miktarının Artış Nedenlerini Değerlendirilmesi } \\
\hline Puan & NA & TAD & IA & EGA & TMEK & ÇBY \\
\hline $\mathbf{1}$ & 7 & 4 & 2 & 18 & 7 & 4 \\
\hline $\mathbf{2}$ & 9 & 9 & 7 & 10 & 7 & 6 \\
\hline $\mathbf{3}$ & 11 & 22 & 9 & 31 & 27 & 17 \\
\hline $\mathbf{4}$ & 25 & 45 & 21 & 30 & 42 & 15 \\
\hline $\mathbf{5}$ & 106 & 78 & 119 & 69 & 75 & 116 \\
\hline Toplam & $\mathbf{1 5 8}$ & $\mathbf{1 5 8}$ & $\mathbf{1 5 8}$ & $\mathbf{1 5 8}$ & $\mathbf{1 5 8}$ & $\mathbf{1 5 8}$ \\
\hline Ortalama & 4,354 & 4,165 & 4,570 & 3,772 & 4,082 & 4,475 \\
\hline Genel Ortalama
\end{tabular}

NA: Nüfus artışı, TAD: Tüketim alışkanlıklarındaki değişim, İA: İsrafin artması, EGA: Ekonomik alım gücündeki artıs, TMEK: Tüketim malzemelerine erişimin kolaylığ, ÇBY: Çevre bilicinin yeterli düzeyde olmaması 
Calıșma kapsamında katılımcılara cevre bilinci konusunda kapalı uçlu sorular sorulmuştur. Öncelikle "Çevre koruma, atıkların geri dönüşümü-atık yönetimi gibi konularda herhangi bir bilgilendirme toplantısına (kongre, sempozyum, sunu, ders vb.) katıldınız mi?" sorusu sorulmuştur. Katılımcıların \%43'ü evet, \%57'si hayır cevabını vermiştir. Katılımcıların \%4,5'i az; \%32,8'i orta; \%44,8'i çok; \%17,9'u çok fazla cevabını işaretleyerek yapılan toplantının kendisine katkısını değerlendirmiştir. Katılımcılara "Katıldı̆̆ınız bilgilendirme toplantısında (kongre, sempozyum, sunu, ders vb.) edindiğiniz bilgileri uygulamaya geçirme düzeyinizi seçiniz." sorusu sorulduğunda katılımcıların \%3'ü nadiren; \%19,4'ü bazen; \%56,7'si sık sık; \%20,9'u her zaman cevabını işaretlemiştir. Hiçbir zaman cevabını işaretleyen olmamıştır.

Anket katılımcılarına "Çevrenizdeki insanlara atıkların geri dönüşümü konusunda uyarıda bulunur musunuz?" sorusu sorulmuştur. Katılımcıların \%3,2'si hiçbir zaman; \%12'si nadiren; \%45,6's1 bazen, \%22,2'si sik sik; $\% 17,1$ 'i her zaman cevabını vermiștir.

Katılımcılardan geri dönüşüm konusunda kendi bilinç düzeylerini değerlendirmeleri istenmiştir. Katılımcıların, \%1,3'ü çok az; \%12'si az; \%33,5'i orta; \%44,9'u iyi; $\% 8$,2'si çok iyi cevabını vermiştir. Katılımcılardan çevresindeki insanların geri dönüşüm bilincinin değerlendirilmesi istendiğinde, \% 29,1'i çok az; \%42,4'ü az; \%22,8'i orta; $\% 2,5$ 'i çok; $\% 3,2$ 'si çok iyi cevabını vermiştir.

Ankete katılan katılımcılara "Yaşadığınız çevrede plastik, metal, kağıt gibi atıkların ayrı ayrı toplanması için yeterli geri dönüşüm kutusu var mıdır?" sorusu sorulmuştur. Katılımcıların \%54,4'ü çok az; \%20,9'u az; \%19,6'sı orta; \%3,2'si iyi; \%1,9'u çok iyi cevabını vermiştir. Son olarak katılımcılardan yaşadı̆̆ınız çevredeki yerel yönetimlerin, kamu kurum ve kuruluşlarının geri dönüşüm konusunda attığı adımları değerlendirmesi istenmiştir ve katılımcıların \%41,1'i çok az; \%27,8'i az; \%25,3'ü orta; \%4,4'ü iyi; \%1,3'ü çok iyi cevabını vermiştir.

\subsection{Atık Yönetimi ve Çevre Bilinci Ölçeği Güvenilirlik Değerlendirmesi}

Çalışmanın bu kısmında, ana başlık altında yöneltilen farklı ifadelere verilen puanların ortalamaları ve katılımcılara sorulan kapalı uçlu soruların güvenirliği, Cronbach's Alpha Testi ile ölçülmüştür (Tablo 10). Ölçeğin güvenirlik katsayısının 0,716 olmasından dolayı ölçek güvenilir kabul edilmektedir.

Tablo 10. Atık Yönetimi ve Çevre Bilinci Ölçeği Güvenilirlik Testi

\begin{tabular}{|c|c|}
\hline Ölçek & Cronbach's Alpha \\
\hline Güvenirlik Katsayısı & 0,716 \\
\hline
\end{tabular}

\subsection{Atık Yönetimi ve Çevre Bilinci Ölçeği Farklılık Testleri}

Atık yönetimi ve çevre bilinci çalışması dâhilinde cinsiyet değişkenin arasında anlamlı farklılığı test etmek için "T testi" uygulanmıștır. Test sonuçları, ifade tipleri arasında anlamlı farklılık göstermemiştir.

Çalışmada öğrencilerin, yaşları, gelir düzeyleri, öğrenim gördükleri birim arasında anlamlı farklılık olup olmadığını anlamak için "Anova" testi uygulanmıştır. Yaş, öğrenim görülen birim arasında anlamlı bir farklılığa rastlanmamıştır. Gelir düzeyi değişkeni, sürdürülebilir çevre için alınan önlemler ve geri dönüşüm bilinci konusunda medya organlarının etki derecelendirmesinde anlamlı farklılığa rastlanmıştır. Sürdürülebilir çevre için alınan kişisel önlemler konusunda 1000 TL alt1 gelire sahip olanlar ile 10012000 TL gelire sahip öğrenciler arasında anlamlı farklılık bulunmaktadır ve 1001-2000 TL gelirli öğrencilerin kişisel olarak aldıkları önlemlere verdikleri puan ortalamasının daha fazla olduğu görülmektedir. 3000 TL üstü gelire sahip olan katılımcılar ile 1000 TL altı gelire sahip olan katılımcılar arasında anlamlı bir fark yokken 1000-2001 TL ve 2001-3000 TL aras1 gelire sahip olan katılımcilar arasında anlamlı fark gözlenmektedir. Gelir düzeyi 1001-2000 TL olan ve 2001-3000 TL olan katılımcıların sürdürülebilir çevre için kişisel önlemlere daha fazla önem verdiği görülmektedir (Tablo 11).

Tablo 11. Gelir düzeyine göre anlamlı farklılık gösteren ifadeler

\begin{tabular}{|c|c|c|}
\hline & Anova & Varyans homojenliği \\
\cline { 2 - 3 } & sig. & sig. \\
\hline ÇKÖ ortalama &, 000 &, 004 \\
\hline AMN ortalama &, 006 &, 416 \\
\hline \multicolumn{2}{|c|}{ ÇKÖ: Sürdürülebilir çevre için alınan kişisel önlemler, GME: Geri }
\end{tabular}

dönüsüm bilinci konusunda medya organlarının etki derecelendirmesi.

Geri dönüşüm konusunda anlamlı farklılık gösteren katılımcı gruplarına bakıldığında 1000 TL altı gelire sahip olan katılımcilar ve 2001-3000 TL gelire sahip olan katılımcilar arasında bir anlamlı farklılık gözlenmiştir. 2001-3000 TL gelire sahip olan katılımcılar medya etkisine daha fazla puan vermişlerdir. Ayrıca 2001-3000 TL ve 3000 TL üstü gelire sahip olan katılımcılar arasında anlamlı bir farklılık gözlenmektedir ve 2001-3000 TL gelire sahip olanların medya organlarının etkisine daha fazla önem verdiği görülmektedir (Tablo 11).

Katılımcılara "Çevre koruma, atıkların geri dönüşümüatık yönetimi gibi konularda herhangi bir bilgilendirme toplantisina (kongre, sempozyum, sunu, ders vb.) katıldınız mı?" sorusu sorulmuştur. Soruya evet cevabını veren katılımcılar ve hayır cevabını veren katılımcılar arasında, atıkların çevre üzerine zararının derecelendirilmesi ve sürdürülebilir çevre için unsurların öneminin derecelendirilmesi ifadelerinde anlamlı bir farklılık gözlenmiştir (Tablo 12). Bağımsız örnekler testine ( $\mathrm{T}$ testi) göre evet cevabını veren katılımcıların atıkların çevre üzerine etkisini ve sürdürülebilir bir çevre için enerji tasarrufu, su tasarrufu, geri dönüşüm gibi unsurların önemini daha yüksek puanla derecelendirmiștir.

Katılımcılara "Çevrenizdeki insanlara atıkların geri dönüşümü konusunda uyarıda bulunur musunuz?" sorusu sorulmuştur. Katılımcıların bu soruya verdikleri 
cevaplar ile sürdürülebilir çevre için unsurların önem derecesi, geri dönüşüme katılımcıların kişisel katk1 derecelendirmesi sürdürülebilir çevre için alınan kişisel önlemler ve atık miktarının artış nedenlerinin derecelendirilmesi ifadelerine verdikleri puan derecelendirmesi arasında anlamlı bir farklılık saptanmıştır (Tablo 13).

Tablo 12. Çevre koruma, atıkların geri dönüşümü - atık yönetimi konularında herhangi bir etkinliğe katılan deneklerin farklılık testi sonuçları

\begin{tabular}{|c|c|c|c|c|c|}
\hline & Cevap & $\mathrm{n}$ & Ortalama & $\begin{array}{l}\text { Levene Eşit } \\
\text { Varyans } \\
\text { Testi (sig.) }\end{array}$ & $\begin{array}{c}\text { T testi } \\
\text { (sig.2-tailed) }\end{array}$ \\
\hline \multirow{2}{*}{$\begin{array}{c}\text { AÇE } \\
\text { ortalama }\end{array}$} & Evet & 68 & 3,982 & \multirow{2}{*}{,412 } & \multirow{2}{*}{,027 } \\
\hline & Hayır & 90 & 3,784 & & \\
\hline \multirow{2}{*}{$\begin{array}{c}\text { SÇU } \\
\text { ortalama }\end{array}$} & Evet & 68 & 4,517 & \multirow{2}{*}{,284 } & \multirow{2}{*}{,042 } \\
\hline & Hayır & 90 & 4,244 & & \\
\hline
\end{tabular}

Post Hoc testlerin sonuçlarına bakıldığı zaman, nadiren, bazen, sık sık, her zaman cevabını veren katılımcılar sürdürülebilir çevre için unsurların önemi derecelendirmesi konusunda arasinda anlamlı farklılık yoktur. Fakat hiçbir zaman cevabını veren katılımcıların diğer cevapları veren katılımcılar arasında anlamlı farklılık gözlenmektedir. Hiçbir zaman cevabını veren katılımcıların de sürdürülebilir bir çevre için unsurların önemine daha az puan vermişlerdir. Geri dönüşüm konusunda kişisel önlemler derecelendirmesinde, soruya nadiren ve her zaman; bazen ve her zaman; sık sik ve her zaman cevabını veren katılımcılar arasında anlamlı bir farklılık bulunmuştur. Her zaman cevabını veren katılımcılar geri dönüşüme daha fazla katkıda bulunduklarını belirtmiştir. Sürdürülebilir bir çevre için alınan kişisel önlemler derecelendirmesinde, hiçbir zaman ve nadiren; hiçbir zaman ve bazen; hiçbir zaman ve sık sık; hiçbir zaman ve her zaman cevapları veren katılımcılar arasında anlamlı bir farklılık bulunmuştur. Hiçbir zaman cevabını veren katılımcılar, sürdürülebilir bir çevre için alınan önlemlere daha düşük derecelendirmişlerdir. Atık miktarının artış nedenlerinin derecelendirmesinde, hiçbir zaman ve nadiren; hiçbir zaman ve bazen; hiçbir zaman ve sık sık; hiçbir zaman ve her zaman cevapları veren katılımcılar arasında anlamlı bir farklılık bulunmuştur. Hiçbir zaman cevabını veren katılımcılar atık miktarının artış nedenlerini daha düşük derecelendirmişlerdir.

Tablo 13. Çevresindekileri geri dönüşüm konusunda uyaran katılımcıların farklılık testi sonuçları

\begin{tabular}{|c|c|c|}
\hline & Anova & Varyans homojenliği \\
\cline { 2 - 3 } & sig. & sig. \\
\hline SÇU ortalama &, 001 &, 108 \\
\hline GKK ortalama &, 003 &, 011 \\
\hline ÇKÖ ortalama &, 000 &, 248 \\
\hline AMN ortalama &, 001 &, 076 \\
\hline
\end{tabular}

SCU: Sürdürülebilir çevre için unsurların önem derecesi, GKK: Geri dönüșüme deneklerin kişisel katk derecelendirmesi, ÇKÖ: Sürdürülebilir çevre için alınan kişisel önlemler, AMN: Atık miktarının artış nedenlerinin derecelendirilmesi.

Katılımcıların geri dönüşüm konusunda kendi bilinç düzeylerini değerlendirmeleri istenmiştir. Katılımcıların bu soruya verdikleri cevaplar ile atıkların kaynaklar üzerine baskı derecesi, geri dönüşüm bilinci konusunda medya organlarının etki derecelendirmesi arasında anlamlı bir farklılık saptanmıștır. Post Hoc testlerin sonuçlarına göre soruya, çok az ve orta; çok az ve iyi, çok az ve çok iyi cevabını veren katılımcılar arasında atıkların kaynaklar üzerine bask1 derecesi konusunda anlamlı farklılık bulunmuştur. Kişisel bilinç düzeyine verilen puanlar arttıkça, atıkların kaynaklar üzerindeki baskısına verilen puanlar da artmaktadır (Tablo 14). Geri dönüşüm bilinci konusunda medya organlarının etki derecelendirmesi, soruya az ve çok iyi cevabını veren katılımcılar arasında anlamlı bir farklılık bulunmuștur. Çok iyi cevabını veren katılımcıların medya organlarının etkinliğine daha fazla puan vermişlerdir.

Tablo 14. Katılımcıların kişisel bilinç düzeylerini değerlendirmesi sonucu farklılık testi sonucları

\begin{tabular}{|l|c|c|}
\hline \multirow{2}{*}{ AKB ortalama } & Anova & Varyans homojenliği \\
\cline { 2 - 3 } & sig. & sig. \\
\hline GME ortalama &, 009 &, 235 \\
\hline AKB: Atıkların Kaynaklar Üzerine Baskı Derecesi, GME: Geri \\
dönüşüm bilinci konusunda medya organlarının etki derecelendirmesi.
\end{tabular}

Katılımcılara sorulan "Yaşadığınız çevrede plastik, metal, kağıt gibi atıkların ayrı ayrı toplanması için yeterli geri dönüşüm kutusu var mıdır?" sorusuna verilen cevaplar ile sürdürülebilir çevre için unsurların önem derecesi, geri dönüşüme katılımcıların kişisel katkı derecelendirmesi, geri dönüșüm bilinci konusunda medya organlarının etki derecelendirmesine ilişkin sorulara verilen cevaplar arasinda anlamlı farklılık saptanmıştır. Post Hoc test sonuçlarına göre soruya az ve çok iyi; orta ve çok iyi cevabını veren katılımcılar arasında sürdürülebilir çevre için unsurların önem derecesi konusunda anlamlı farklılık saptanmıştır.

\section{SONUC}

Araştırma sonuçları değerlendirildiğinde, ankete katılanların yaş, okudukları fakülte/myo/bölüm ve sınıf bazındaki farklılığın anket sonuçlarında anlamlı bir farklılık oluşturmadığı saptanmıştır. Gelir düzeyi açısından bir değerlendirme gerçekleştirildiğinde ise geri dönüşüme ilişkin kişisel katkı düzeyinin orta gelir grubunda daha yüksek olduğu görülmektedir. Uzun ve Sağlam [27]'ın orta öğretim düzeyindeki öğrencilerin çevre bilinç düzeyini ölçmeye yönelik gerçekleştirdikleri çalışmada benzer şekilde orta gelir düzeyinin bilinç düzeyi daha yüksek olarak ölçülmüsstür.

Katılımcılara çevre koruma, atıkların geri dönüşümü, atık yönetimi gibi konularda herhangi bir bilgilendirme toplantısına katılıp katılmadıkları sorulmuș ve deneklerin \%57'si hayır cevabını vermiştir. Tufaner [28], Adıyaman Üniversitesi'nde gerçekleştirdiği çalışmada atık geri dönüşümü konusunda yapılan bilgilendirme toplantılarının, kaynağından ayrıştırma yoluyla geri dönüşüme katkısının önemli oranda artışına sebep olduğu sonucuna varmıştır. Jekria and Daud [29], çevresel kaygıların geri dönüșüm davranışları üzerinde olumlu etki oluşturduğunu, Miranda and Blanco [21], ise eğitim süreçlerine dâhil edilen bir takım programların dolaylı olarak ebeveyn tutum ve davranışlarını da olumlu yönde etkileyeceğini belirtmişlerdir. Bu bağlamda tüm eğitim kademelerinde ve özellikle yükseköğrenim 
sürecinde ders içeriklerinde çevre konu / konularına yer verilmesi, dönemsel bilgilendirme toplantıları ve aktivitelerinin gerçekleştirilmesi çevre bilicinin geliştirilmesi için son derece önemli görülmektedir.

Çalışma kapsamında bu konuda herhangi bir bilgilendirme toplantısına katılanların, atık maddelerin çevre üzerindeki zararı, sürdürülebilir bir çevre için unsurların puanlandırılmasına olan katkı derecelerinin daha yüksek olduğu ancak kişisel önlemlere katkılarında anlamlı bir farklılık olmadığı saptanmıștır. Ankete katılanların önemli çoğunluğu yaşadıkları çevrede plastik, metal, kağıt gibi atıkların ayrı ayrı toplanması için yeterli geri dönüşüm kutusunun bulunmadığını ve yerel yönetimler, kamu kurum ve kuruluşlarının geri dönüşüm konusunda attığı adımların yeterli düzeyde olmadığını belirtmişlerdir. Yapılan araştırmalar çevresel konularda duyarlılık kazanmış kişilerin, geri dönüşüm konusunda daha etkin katılım sağladığını gösterirken $[21,30]$. Thogersen and Olander [23], gerçekleştirmiş oldukları çalışmada, geri dönüşüme katkı sağlama oranının yaşanılan yerdeki atık toplama ve geri dönüşüm hizmetleriyle de doğrudan bağlantılı olduğu sonucuna varmışlardır. $\mathrm{Bu}$ noktadan hareketle geri dönüşüme bireysel katkının arttırılması amacıyla, gerek yerel yönetimler gerekse kamu kurum ve kuruluşlarınca, atıkların kaynağında ayrıştırılması için yeterli ekipmanların temin edilmesi ve eğitsel faaliyetlerin sürekliliğinin sağlanması gerekmektedir.

Gerçekleştirilen anket sonuçları doğrultusunda atık yönetimi- geri dönüşümü konusunda bilinç oluşturmada medya organlarından internet ve televizyonun etkilerinin daha yüksek olduğu sonucu ortaya çıkmaktadır. Söz konusu medya organlarında özellikle Z kuşağında bilinç ve uygulama düzeyini arttırmaya yönelik ilgi çekici içeriklerin sürekliliği önem taşımaktadır. Yükseköğretim kurumlarında sosyal etkileşimin daha yüksek olduğu kantin, yemekhane, kafeterya ve sosyal tesisler gibi ortak kullanım alanlarında görsel ve işitsel iletişim araçları ile bilgilendirici yayınların yapılmasının da atık yönetimi ve çevre bilinci konusunda katkı sağlayacağı düşünülmektedir.

\section{KAYNAKLAR}

[1] Keleş R, Hamamcı C. Çevrebilim. İmge kitabevi yayınları. Ankara; 2002.

[2] Anonim 1983. http://www.mevzuat.gov.tr/MevzuatMetin/1.5.2872 .pdf (Erişim tarihi: 22.03.2020).

[3] Diksaç R. Çevre bilinci ve yaşam tarzının sürdürülebilir tüketim davranışı üzerindeki etkisi ve bir araştırma [Yüksek lisans tezi]. İstanbul: Marmara Üniversitesi; 2019.

[4] Akın G. Küresel çevre sorunları. C.Ü. Sosyal bilimler dergisi. 2007; 31(1): 43-54.

[5] Alım M. Avrupa Birliği üyelik sürecinde Türkiye'de çevre ve ilköğretimde çevre eğitimi. Kastamonu eğitim dergisi. 2006;14(2): 599-616.

[6] Uydacı M. Yeşil pazarlama. Türkmen yayınevi. İstanbul; 2017.
[7] Kim Y, Choi S.M. Antecedents of green purchase behaviour: An examination of collectivism, environmental concern and PCE. Advances in customer research. 2005; 35: 592-599.

[8] Anonim. http://www.mfa.gov.tr/i_-temel-cevresorunlari.tr.mfa (Erişim tarihi: 06.04.2020)

[9] Hayta A.B. Çevre kirliliğinin önlenmesinde ailenin yeri ve önemi. Ahi Evran Üniversitesi Kırşehir eğitim fakültesi dergisi (KEFAD). 2006; 7(2): 359376.

[10] Anonim. https://www.bbc.com/turkce/haberlerdunya-48851661 (Erişim tarihi: 08.04.2020).

[11] Anonim. https://webdosya.csb.gov.tr/db/cygm/editordosya/G eri Kazanim ve Biz.pdf (Erişim tarihi: 10.04.2020).

[12] Anonim. https://www.netpakambalaj.com/tr/ulkemizde-geridonusum-h-38 (Erişim tarihi: 08.04.2020).

[13] Anonim. https://www.netpakambalaj.com/tr/geridonusum-konusunda-en-basarili-ulkeler-h-37 (Erişim tarihi: 08.04.2020)

[14] Anonim 2018. TMMOB Çevre Mühendisleri Odas1, Dünya Çevre Günü Türkiye Raporu. https://www.cmo.org.tr/resimler/ekler/0d4a5b926c 005a6 ek.pdf (Erişim tarihi: 14.09.2020).

[15] Sawin J.L. enerji seçimlerini daha iyi yapmak. Ed. Assadourian vd., (çev. Ayşe Başçı Sander), Dünyanın Durumu 2004. Worldwatch EnstitüsüTEMA Vakfi. İstanbul; 2004.

[16] Aydın M, Deniz K. Atık yönetiminde vergi politikasının rolü: Türkiye değerlendirmesi. Yönetim bilimleri dergisi, 2017; 15(30): 435-461.

[17] Anonim. https://cevreonline.com/atik-yonetimi/ (Erişim tarihi 13.03.2020).

[18] Anonim 2015. Atık Yönetimi Yönetmeliği, Resmî Gazete. https://www.resmigazete.gov.tr/eskiler/2015/04/20 150402-2.htm (Erişim tarihi: 13.07.2020).

[19] Anonim. T.C. Çevre ve Şehircilik Bakanlığı, Ulusal Atık Yönetimi ve Eylem Planı 2023. https://webdosya.csb.gov.tr/db/cygm/haberler/ulusa 1_at-k_yonet-m--eylem_plan--20180328154824.pdf (Erişim tarihi: 11.05.2020).

[20] Anonim. https://sifiratik.gov.tr/sifir-atik/sifir-atiknedir (Erişim tarihi 07.04.2020).

[21] Miranda R, Blanco A. Environmental awareness and paper recycling. Cellulose chemistry and technology. 2010; 44(10): 431-449.

[22] Vural H, Yılmaz S. Ortaokul Öğrencilerinin çevre ve doğa ile ilgili konularda bilgi ve davranış düzeylerinin belirlenmesi; Erzurum ili örneği. Iğdır Üniversitesi fen bilimleri enstitüsü dergisi. 2016, 6(1): 107-115.

[23] Thogersen J, Olander F. The dynamic interaction of personal normsand environment-friendly buying behavior: A panel study. Journal Of Applied Social Psychology. 2006; 36(7): 1758-1780.

[24] Anonim. http://www.bingol.edu.tr/tr/universitemiz/genel/say ilarla-bingol-universitesi.(Erişim tarihi: 06.03.2021) 
[25] Özdamar K. Modern bilimsel araştırma yöntemleri. Kaan kitapevi. Eskişehir; 2003.

[26] George D, Mallery P. IBM SPSS statistics 26 Step by step, a simple guide and reference (E-Book). New York and London: Routledge, Taylor \& Francis Group; 2020.

[27] Uzun N, Sağlam N. Sosyo-ekonomik durumun çevre bilinci ve çevre akademik başarısı üzerindeki etkisi. Hacettepe Üniversitesi eğitim fakültesi dergisi (H. U. Journal of Education). 2005; 29: 194202.

[28] Tufaner F. Geri dönüşebilir atıkların toplanması konusunda yapılan bilgilendirme çalışmalarının toplama verimine katkısının araştırılması. İklim değişikliği ve çevre. 2019; 4 (1): 33-40.

[29] Jekria N, Daud S. Environmental concern and recycling behaviour. Procedia Economics and Finance. 2016; 35: $667-673$.

[30] Domina T, Koch K. Convenience and frequency of recycling: İmplications for including textiles in curbside recycling programs. Environment and behavior. 2002; 34: 216-38. 